\title{
Microbiological analysis and detection of anti-bacterial activity of Centella asiatica and Aloe vera samples collected from different areas of Dhaka city, Bangladesh
}

\author{
Susmita Bhowmik, Runa Akter Chowdhury and Md. Aftab Uddin* \\ Department of Microbiology, Stamford University Bangladesh, 51 Siddeswari Road, Dhaka 1217, Bangladesh
}

Received 23 September 2016/Accepted 27 October 2016

\begin{abstract}
The present study was performed to detect the presence of contaminating microorganisms in two commonly available herbal samples (Centella asiatica and Aloe vera) collected from different areas of Dhaka city, Bangladesh and to assess their antibacterial activity. Out of twenty samples (having ten samples of each categories) studied; the range of total viable bacterial count was approximately $10^{3}$ to $10^{8} \mathrm{cfu} / \mathrm{g}$. Presence of Staphylococcus aureus was found in all the samples, followed by Klebsiella spp. in 15 samples, Pseudomonas spp. in 14 samples, Bacillus spp. in 12 samples, Escherichia coli in 9 samples and Vibrio spp. in 7 samples. Salmonella spp. was detected in neither of the sample. 17 samples showed a high fungal load up to $10^{7} \mathrm{cfu} / \mathrm{g}$. Antibacterial activity of $C$. asiatica samples was demonstrated against eight laboratory isolates. Only four $C$. asiatica samples showed activity against Klebsiella spp. On the contrary, Aloe vera samples (12-14) showed antibacterial activity only against Staphylococcus spp.
\end{abstract}

Key words: Centella asiatica; Aloe vera; Contamination; Antimicrobial activity

Besides a mass practice of antibiotics to fight diseases, most of the medicines have been derived from natural resources around the world until now (1-3). Many antibiotics have become out-of-date due to the appearance of resistant or even the multidrug-resistant strains, or reported to be associated with undesirable side effects (4-6). Researchers have found that, bacterial resistance to tetracycline; penicillin and erythromycin are encoded by over 100 different genetic mechanisms, a number of which are readily transferable to other bacteria via conjugal elements, transposons, plasmids etc (7). Therefore, inauguration of herbal medication could be an alternate to treat diseases caused by multidrug resistant bacteria $(8,9)$. Some other reasons for the practice of herbal medicines include the minor side effects with small or no toxicity, cheap in price, better ease of access etc. $(10,11)$. Therefore, more researches are going on focused onto developing drugs from herbal sources with slightest or no side effects having better outcome (12).

C. asiatica is a small stonoliferous, perennial, frosttender creeping aromatic plant belonging to the family Apiaceae (Umbelliferae) and subfamily Mackinlaya (13), which was formerly included in hydrocotyle (14). In ancient times, Centella asiatica and its extracts was

*Corresponding Author: Mailing address. Md. Aftab Uddin, Department of Microbiology, Stamford University Bangladesh, 51 Siddeswari Road, Dhaka 1217, Bangladesh, Bangladesh; E-mail: aftab_mb12@yahoo.com. used for the treatment of various skin disease such as leprosy, lupus, varicose ulcers, eczema, psoriasis, diarrhea, fever, and diseases related to the female genitourinary tract (15). Various reports have claimed that Centella asiatica have been used conventionally in decreasing high blood pressure, treating a range of deficiencies, enhancing memory and brainpower, easing nervousness and wound repairing (16).

Aloe vera is a member of liliaceae family. Aloe vera (Synonym A. brobadensis) is a cactus like plant with green, dagger- shaped leaves that are fleshy, tapering. Aloe vera gel is extensively used in gastrointestinal disorders including peptic ulcer (17). A. vera has been used to treat numerous skin conditions such as cuts, burns and eczema. There are suggestions on the properties of $A$. vera juice on wound healing (18). There are several studies on A. vera which are considerable. Ethanolic extracts of $A$. vera showed advanced antibacterial activity than aqueous extract (19).

Medicinal plants horde a wide spectrum of microorganisms with various individual properties and with considerable differences regarding qualitative \& quantitative aspects. In principle, the microbial load of plants is the result of a series of influences caused by animate \& inanimate sources and microbial contaminates are easily transferred via air and soil borne vectors (2023). Furthermore, original microflora in plants, presence of microorganisms within processing plant, dust, using contaminated water and animal human 
excreta, before and after harvest procedure including processing, storage and distribution may be the origins of microbial contamination $(20,24)$. In addition, the collection and handling of medicinal plants does not usually done in sanitary conditions and unhygienic cultivation conditions can increase pollution, influence the maintenance period and destruct the aspect and the potential advantage of medicinal plants $(9,25)$.

Although there are several reports based on the determination of antibacterial activity of $C$. asiatica \& A. vera, little is known about the harboring microorganism associated with these samples. Based on these facts and considerations, the recent study not only deals with the evaluation of antibacterial efficacy of the crude extracts of these herbal plants, but also to measure their level of bacterial contamination when collected from the market places from various areas of Dhaka city.

\section{MATERIALS AND METHODS}

Collection of samples \& processing. 10 Centella asiatica samples and 10 Aloe vera samples were collected randomly for the detection of microbiological analysis and antibacterial activity from different locations of Dhaka city within a period of October 2015 to November 2015. Samples were collected early in the morning and transported quickly to the laboratory according to the standard scheme. For preparing the sample suspension for microbiological examinations, $10 \mathrm{~g}$ of each sample was weighed and homogenized in $90 \mathrm{ml}$ normal saline to prepare $100 \mathrm{ml}$ sample suspension. Then, it was subjected to serial dilution (made up to $10^{-5}$ ) for microbiological analysis $(9,26-29)$.

Total viable bacterial count (TVBC), total bacilli count and total fungal count. $0.1 \mathrm{ml}$ from $10^{-2} \& 10^{-5}$ dilution of each sample was spread over nutrient agar (NA) for TVBC \& $0.1 \mathrm{ml}$ from $10^{-2}$ dilution was spread over Starch agar and SDA plate for the detection of Bacillus spp. and total fungal load respectively $(26,27,30)$.

Determination of Pseudomonas spp., Staphylococcus spp., Escherichia coli, \& Klebsiella spp. $0.1 \mathrm{ml}$ sample from $10^{-2} \& 10^{-5}$ dilution was spread on Cetrimide agar, MSA (Mannitol Salt Agar), MAC (MacConkey Agar) for the determination of Pseudomonas spp., Staphylococcus spp. and coliform, respectively and incubated overnight at $37{ }^{\circ} \mathrm{C}(27,28,31)$.

Detection of Vibrio spp., Salmonella spp., and Shigella spp. As Vibrio spp., Salmonella spp. and Shigella spp. remain in the environment as viable but nonculturable (VBNC) state, they do not appear readily during microbiological test procedures. Before conducting serial dilutions, $1 \mathrm{ml}$ of $10^{-2}$ diluted samples were enriched with alkaline peptone water (APW) for Vibrio spp. and selenite cystein broth (SCB) for Salmonella spp. \& Shigella spp. at $37{ }^{\circ} \mathrm{C}$ for $2-4 \mathrm{hrs}$. The samples were then spread on the SS agar and TCBS agar for detecting Salmonella spp. (with black precipitates), Shigella spp. (reddish or pink color) \& Vibrio spp. (small, yellow colored colony) $(27,28,31)$.

Determination of antibacterial activity of the herbal plants. The antibacterial activity of the samples was carried out by using agar well diffusion method. At first, the suspension (with standard turbidity compared to that of McFarland standard of 0.5) of each of the test bacteria (Escherichia coli, Bacillus spp., Staphylococcus spp., Vibrio spp., Salmonella spp., Pseudomonas spp., Klebsiella spp., \& Listeria spp.) were spread evenly over the MHA using cotton swab which in turn resulted into uniform lawns. Wells made in the MHA was generated by cork-borer. Each of the samples then introduced separately in

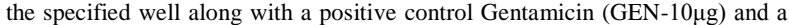
negative control (normal saline). Existence of clear zone surrounding the sample solution (if any) was indicative of the presence of antibacterial activity of the samples tested $(26,27,32,33)$.

\section{RESULTS AND DISCUSSIONS}

In the ancient times, plants have been a source of medicine and today scientists and the public recognize their value as a source of new or complimentary medicinal products (34). The traditional system of medicine in particular herbal medicine is in great demand in developed as well as in developing countries because of their lesser side effect, wide biological activities and lesser cost than synthetic drugs $(9,35)$.

However, Medicinal plants could be subjected to a wide range of microbial contamination during pre and post harvest stages and they can harbor high microbial loads. Researchers investigated the microbial load of medicinal plants \& spices and found the presence of different contamination including pathogenic bacteria such as Staphylococcus aureus, Shigella spp., Salmonella, Escherichia coli, Clostridium perfringens, fungi, molds, mesophilic aerobic bacteria (total count) and Enterobacteriaceae $(36,38,39)$. In this study, all herbal samples ( $C$. asiatica \& Aloe vera) were found to exhibit huge load of total viable bacteria within the range of $10^{3}$ to $10^{8} \mathrm{cfu} / \mathrm{g}$ as shown in Table 1. Here, Staphylococcus aureus was present in all the samples, followed by Klebsiella spp. (in 15 samples), Pseudomonas spp. (in 14 samples), Bacillus spp. (in 12 samples), E. coli (in 11 samples) and Vibrio spp. (in 10 samples). Salmonella spp. was absent in all samples (Table 1). This result was quite similar with the study conducted by Le et al. (39). Here, 19 samples showed a high fungal load up to $10^{7} \mathrm{cfu} / \mathrm{g}$, which can be indicative to the presence of various mycotoxins in the food samples that may pose severe threat to the human health (39). Also, Presences of the high load of other contaminating pathogenic bacteria are also a matter of great concern.

Anti-bacterial activity of the herbal sample. Chemically synthesized medicines may have numerous undesirable side effects on our body but natural antimicrobial agents from the herbal plant such as Aloe vera could be used safely in near future as anti-infective. It has several uses as laxative, anti-helminthic, hemorrhoid remedy, and uterine stimulant. It is used often together with licorice root, to treat eczema or psoriasis (42). On the contrary, Centella asiatica and its extracts was documented to be used for the treatment of various skin diseases like leprosy, lupus, varicose ulcers, psoriasis, diarrhea, fever, amenorrhea, and diseases of the female genitourinary tract (27). Some other reports have also claimed that Centella asiatica have been used traditionally in decreasing of high blood pressure, treating a range of deficiencies, enhancing memory and brainpower, easing nervousness and wound repairing (28).

In this present study antibacterial activity of herbal samples (C. asiatica \& Aloe vera) was demonstrated against eight laboratory isolates (Table 2). Only four $C$. asiatica samples (1, 2, 5 and 6) showed activity against Klebsiella spp. On the contrary, Aloe vera samples (12, 13 , 14) showed antibacterial activity against Staphylococcus spp. This result was not similar with the results found by Lalitha et al. (34), Udoh et al. (16), 
TABLE 1. Microbiological analysis of the herbal samples

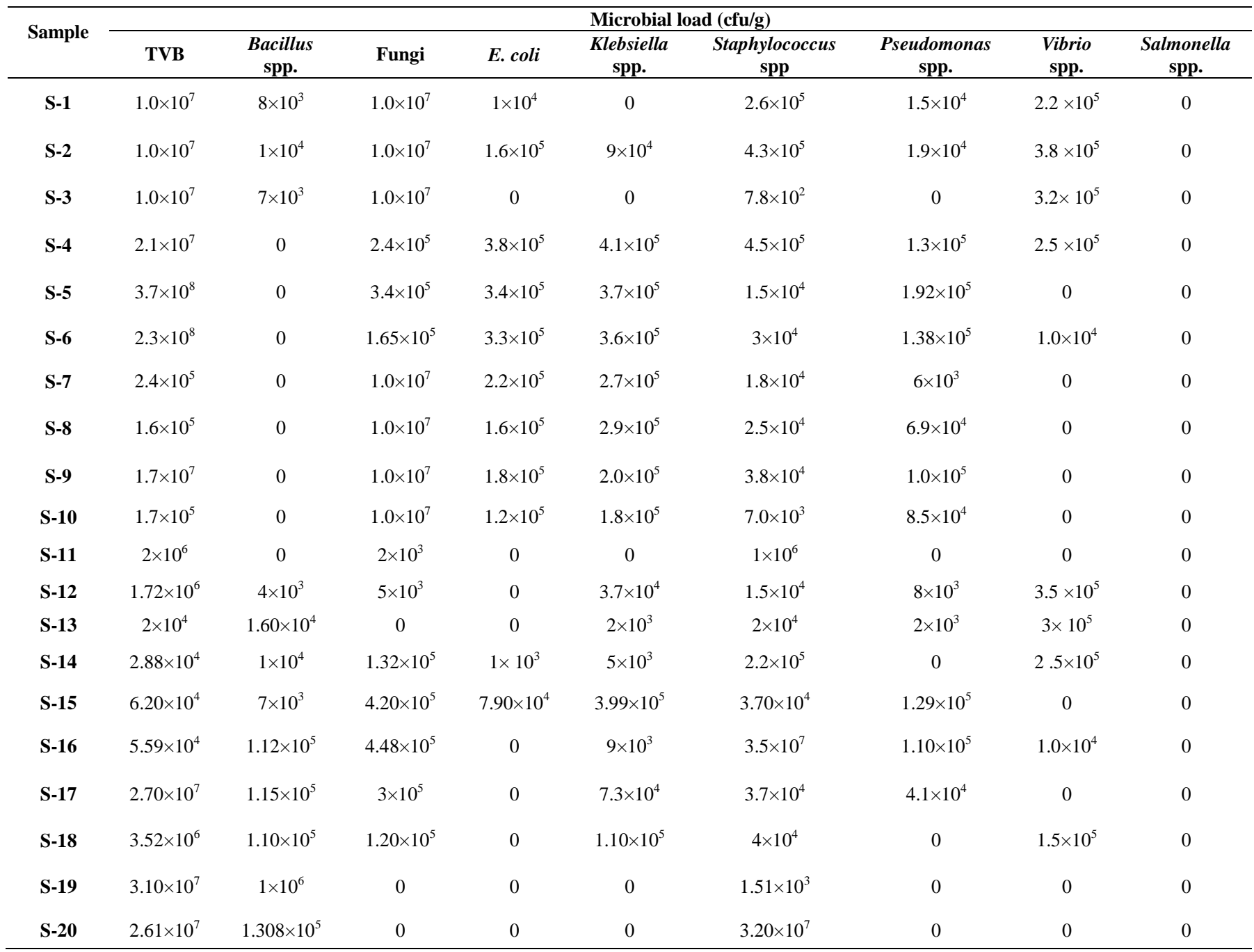

TVB $=$ Total viable bacteria

The average load has been shown

Microbial limit (World Health Organization 2007): Total aerobic bacteria $10^{5} \mathrm{cfu} / \mathrm{ml}$; Escherichia coli $10^{1} \mathrm{cfu} / \mathrm{ml}$; Salmonella spp. absent; Enterobacteria $\left.10^{3} \mathrm{cfu} / \mathrm{ml}\right)$

Irshad et al. (42). The difference in the results of these studies might be due to the employment of the different solvent extraction method (such as methanol or ethanol) for scavenging the bioactive components from the $A$. vera samples \& minimum inhibitory concentration (MIC) procedure which was proved to be worthwhile.

\section{CONCLUSION}

In this study, a variety of bacterial load was observed in Centella asiatica and Aloe vera. Therefore, hygienic conditions must be enhanced in different stages of cultivation, produce, transfer, processing and packaging. Considering the importance of medicinal plants in the human health and the large practice of the medicinal herbs in various forms for disease prevention and cure; culturing, harvesting, conveying and processing of these crops should be done in sanitary conditions. Thus, it is important to control environmental conditions and improvements in hygiene procedures during production and processing of herbs. A suitable sanitization method for disinfection before and when packaging medicinal plants would be recommended. In addition, a further investigation is necessary to assess antimicrobial activity by performing various solvent (ethanol extraction, methanol extraction, hot and cold-water extraction) extraction method. 
TABLE 2. In vitro anti-bacterial activity of herbal samples

\begin{tabular}{|c|c|c|c|c|c|c|c|c|}
\hline \multirow{2}{*}{ Sample } & \multicolumn{8}{|c|}{ Zone of inhibition (mm) } \\
\hline & E. coli & $\begin{array}{c}\text { Klebsiella } \\
\text { spp. }\end{array}$ & $\begin{array}{c}\text { Pseudomonas } \\
\text { spp. }\end{array}$ & $\begin{array}{l}\text { Vibrio } \\
\text { spp. }\end{array}$ & $\begin{array}{c}\text { Staphylococcus } \\
\text { spp. }\end{array}$ & $\begin{array}{l}\text { Listeria } \\
\text { spp. }\end{array}$ & $\begin{array}{c}\text { Bacillus } \\
\text { spp. }\end{array}$ & $\begin{array}{c}\text { Salmonella } \\
\text { spp. }\end{array}$ \\
\hline S-01 & $\mathbf{0}$ & 11 & $\mathbf{0}$ & $\mathbf{0}$ & $\mathbf{0}$ & $\mathbf{0}$ & $\mathbf{0}$ & $\mathbf{0}$ \\
\hline S-02 & $\mathbf{0}$ & 11 & $\mathbf{0}$ & $\mathbf{0}$ & $\mathbf{0}$ & $\mathbf{0}$ & $\mathbf{0}$ & $\mathbf{0}$ \\
\hline S-03 & $\mathbf{0}$ & $\mathbf{0}$ & $\mathbf{0}$ & $\mathbf{0}$ & $\mathbf{0}$ & $\mathbf{0}$ & $\mathbf{0}$ & $\mathbf{0}$ \\
\hline S-04 & $\mathbf{0}$ & $\mathbf{0}$ & $\mathbf{0}$ & $\mathbf{0}$ & $\mathbf{0}$ & $\mathbf{0}$ & $\mathbf{0}$ & $\mathbf{0}$ \\
\hline S-05 & $\mathbf{0}$ & 11 & $\mathbf{0}$ & $\mathbf{0}$ & $\mathbf{0}$ & $\mathbf{0}$ & $\mathbf{0}$ & $\mathbf{0}$ \\
\hline S-06 & $\mathbf{0}$ & 11 & $\mathbf{0}$ & $\mathbf{0}$ & $\mathbf{0}$ & $\mathbf{0}$ & $\mathbf{0}$ & $\mathbf{0}$ \\
\hline S-07 & $\mathbf{0}$ & $\mathbf{0}$ & $\mathbf{0}$ & $\mathbf{0}$ & $\mathbf{0}$ & $\mathbf{0}$ & $\mathbf{0}$ & $\mathbf{0}$ \\
\hline S-08 & $\mathbf{0}$ & $\mathbf{0}$ & $\mathbf{0}$ & $\mathbf{0}$ & $\mathbf{0}$ & $\mathbf{0}$ & $\mathbf{0}$ & $\mathbf{0}$ \\
\hline S-09 & $\mathbf{0}$ & $\mathbf{0}$ & $\mathbf{0}$ & $\mathbf{0}$ & $\mathbf{0}$ & 0 & 0 & 0 \\
\hline S-10 & 0 & 0 & 0 & 0 & 0 & 0 & 0 & 0 \\
\hline S-12 & 0 & 0 & 0 & 0 & 18 & 0 & 0 & 0 \\
\hline S-13 & 0 & 0 & 0 & 0 & 14 & 0 & 0 & 0 \\
\hline S-14 & 0 & 0 & 0 & 0 & 14 & 0 & 0 & 0 \\
\hline S-15 & 0 & 0 & 0 & 0 & 0 & 0 & 0 & 0 \\
\hline S-16 & 0 & 0 & 0 & 0 & 0 & 0 & 0 & 0 \\
\hline S-17 & 0 & 0 & 0 & 0 & 0 & 0 & 0 & 0 \\
\hline S-18 & 0 & 0 & 0 & 0 & 0 & 0 & 0 & 0 \\
\hline S-19 & 0 & 0 & 0 & 0 & 0 & 0 & 0 & 0 \\
\hline S-20 & 0 & 0 & 0 & 0 & 0 & 0 & 0 & 0 \\
\hline $\begin{array}{c}\text { Positive } \\
\text { Control } \\
\text { (GEN- } \\
10 \mu \mathrm{g} \text { ) }\end{array}$ & 19 & 18 & 20 & 21 & 19 & 16 & 17 & 18 \\
\hline $\begin{array}{c}\text { Negative } \\
\text { Control } \\
\text { (Normal } \\
\text { Saline) }\end{array}$ & 0 & 0 & 0 & 0 & 0 & 0 & 0 & 0 \\
\hline
\end{tabular}

The experiments were conducted three times independently, and the results were found to be reproducible. One representative data has been shown.

\section{ACKNOWLEDGEMENT}

Authors thank Stamford University Bangladesh for the logistic and financial supports to conduct the study.

\section{REFERENCES}

1. Behera B, Purvia R, Yadav D, Sharma MC. 2013. Review on antidiabetic plants of different nighantus (Ayrvedic Materia Medica) Ayurpharm. Int. J. Ayur. Alli. Sci. 2 (4): 92-97.

2. Cragg GM, Newman DJ. 2013. Natural products: a continuing source of novel drug leads. Biochim. Biophys. Acta. 1830 (6): 3670-3695.

3. Veeresham C. 2012. Natural products derived from plants as a source of drugs. J. Adv. Pharm. Technol. Res. 3 (4): 200-201.

4. Dutta S, Hassan MR, Rahman F, Jilani MSA, Noor R. 2013. Study of antimicrobial susceptibility of clinically significant microorganims isolated from selected areas of Dhaka, Bangladesh. Bangladesh J. Med. Sci. 12 (1): 34-42.

5. Molton JS, Tambyah PA, Ang BS, Ling ML, Fisher DA. 2013. The global spread of healthcare-associated multidrug-resistant bacteria: A perspective from Asia. Clin Infect. 56 (9): 1310-1318.
6. Khan SA, Feroz F, Noor R. 2013. Study of extended-spectrum $\beta$-lactamase producing bacteria from urinary tract infection in Bangladesh. Tzu Chi Med. J. 25 (1): 39-42.

7. Blahova J, Kralikova K, St Krcmery V. 1999. Antibiotic resistance. Cas. Lek. Cesk. 138 (11): 343-347.

8. Djeussi DE, Noumedem JA, Seukep JA, Fankam AG, Voukeng IK, Tankeo SB, et al. 2013. Antibacterial activities of selected edible plants extracts against multidrug-resistant Gram negative bacteria. BMC Complement Altern. Med. 13 (1): 164

9. Sharmin M, Nur IT, Acharjee M, Munshi SK, Noor R. Microbiological profiling and the demonstration of in vitro anti-bacterial traits of the majo oral herbal medicines used in Dhaka Metropolis.. SpringerPlus. 3: 739.

10. Gyasi RM, Mensah CM, Adjei PP, Agyemang S. 2011. Public perceptions of the role of traditional medicine in the health care delivery system in Ghana. Global J. Health Sci. 3 (2): 40-49.

11. World Health Organization. 2013. WHO traditional medicine strategy: 2014-2023. Available at: http://apps.who.int/iris/bitstream/10665/92455/ 1/9789241506090eng.pdf?ua=1. Accessed 13 January, 2016.

12. Ernst E. 2011. Herbal medicine in the treatment of rheumatic diseases. Rheum. Dis. Clin. North Am. 37 (1): 95-102.

13. Liu M, van Wyk BE, Tinley PM. 2003. A taxonomic evaluation of fruit structure in the family Apiaceae, Ph. D thesis. University of Johannesburg, Auckland Park, South Africa. 
14. Brinkhaus B, Linder M, Schuppan D, Hahn EG. 2000. Chemical, pharmacological and clinical profile of the east African medicinal plant Centella asiatica. Phytomedicine. 7 (5): 427-448.

15. Gohil KJ, Patel JA, Gajjar AK. 2010. Pharmacological review on Centella asiatica: A potential herbal cure. Indian J. Pharm. Sci. 72 (5): 546-556.

16. Udoh DI, Asamudo NU, Bala DN, Otung E. 2012. Inhibitory effect of varying concentrations of leaves' extracts of Centella Asiatica (Gotu Kola) on some microorganisms of medical importance. International Journal of Chemical, Environmental and Pharmaceutical Research. 3 (2): 142-148.

17. Thiruppathi S, Ramasubramanian V, Sivakumar T, Thirumalai AV. 2010. Antimicrobial activity of Aloe Vera Burm. F. against pathogenic microorganisms. Journal of Biosciences Research. 1 (4): 251-258.

18. Vogler BK, Ernst E. 1999. Aloe vera: a systematic review of its clinical effectiveness. Br. J. Gen. Pract. 49: 823-828.

19. Choi SW, Son BW, Son YI, Park YI, Lee SK, Chung MH. 2001. The wound-healing effect of a glycoprotein fraction isolated from aloe vera. $\mathrm{Br}$. J. Dermatol. 145 (4): 535-45.

20. Kneifel W, Czech E, Kopp B. 2002. Microbial contamination of medical plants - A review. Planta Medica. 68: 5-15.

21. Noor R. 2016. Microbiological quality of commonly consumed street foods in Bangladesh. Nutrition and Food Science. 46 (1): 130-141.

22. Rahman H, Feroz F, Alam MS, Acharjee M, Das KK, Noor R. 2016. Demonstration of the source of microbial contamination of freshly cultivated cabbage, cauliflower, potato and squash collected from rural farms of Bangladesh. International Food Research Journal. 23 (3):12891295

23. Noor R, Malek M, Rahman MS, Meghla M, Acharjee M, Rahman MM. 2015. Assessment of survival of pathogenic bacteria in raw fresh vegetables through in vitro challenge test. Int. J. Food. Cont. 2 (1): 15

24. Alam MS, Feroz F, Rahman H, Das KK, Noor R. 2015. Microbiological contamination sources of freshly cultivated vegetables. Nutrition and Food Science. 45 (4): 646-658.

25. Valiasill R, Azizi M, Bahreini M, Hossein A. 2014. The survey of microbial quality of the dry sample, extract and brewing of some medicinal plants. Not. Sci. Biol. 6 (4): 478-482.

26. Feroz F, Das JS, Tahera J, Das KK, Noor R. 2014. Investigation of microbiological spoilage and demonstration of the anti-bacterial activity of the major imported fruits within Dhaka Metropolis. Stamford Journal of Microbiology. 4 (1): 1-4.

27. Das JS, Feroz F, Tahera J, Das KK, Noor R. 2014. Assessment of microbiological contamination and the in vitro demonstration of the antibacterial traits of the commonly available local fruit blend within Dhaka Metropolis. Journal of Pharmacognosy and Phytochemistry. 3 (1): 73-77.

28. Cappuccino JG, Sherman N. 1996. Microbiology - A laboratory manual. The Benjamin/Cummings Publishing Co., Inc., Menlo Park, California.
29. American Public Health Association (APHA). 1998. Standard methods for the examination of water and wastewater. American Public Health Association, Washington, D.C.

30. Sultana T, Rana J, Chakraborty SR, Das KK, Rahman T, Noor R. 2014 Microbiological analysis of common preservatives used in food items and demonstration of their in vitro anti-bacterial activity. Asian Pacific Journal of Tropical Disease. 4 (6): 452-456.

31. Akon T, Das KK, Naher LN, Noor R. 2015. Demonstration of in vitro antibacterial activity of the popular cosmetics items used by the Dhaka locality. Asian Pacific Journal of Tropical Disease. 5 (1): S121-S126.

32. Jagessar RC, Mars A, Gones G. 2008. Selective antimicrobial properties of leaf extract against various micro-organisms using disc diffusion and agar well diffusion method. J. Nat. Sci. 6 (2): 24-38.

33. Hussain A, Wahab S, Zarin I, Hussain MDS. 2010. Antibacterial activity of the leaves of Coccinia indica (W. and A) of India. Adv. Biol. Res. 4: 241-

34. Lalitha V, Kiran B, Raveesha KA. 2013. Antibacterial and antifungal activity of aqueous extract of Centella asiatica L. against some important fungal and bacterial species. World Journal of Pharmacy and Pharmaceutical Sciences. 2 (6): 4744-4752.

35. Premanath R, Lakshmideri N. 2010. Studies on antioxidant activity of Tinospora cordifolia (Miers) leaves using in vitro models. J. Am. Sci. 6 (10): 736-743.

36. Abba D, Inabo HI, Yakubu SE, Olonitola OS. 2009. Contamination of herbal medicinal products marketed in Kaduna metropolis with selected pathogenic bacteria. Afric. J. Trad. Complement Altern. Med. 6 (1):70-77.

37. Hashem M, Alamri S. 2010. Contamination of common spices in Saudi Arabia markets with potential mycotoxin-producing fungi. Saudi J. Biol. Sci. 17 (4):167-175.

38. Sospedra I, Soriano JM, Manes J. 2010. Assessment of the microbiological safety of dried spices and herbs commercialized in Spain. J. Plants Food Hum. Nut. 65 (4): 364-368.

39. Le HQC, Thong HT, Nguyen VC, Hung PHS, Vu VH, Le VA, et al. 2014 Microbial and parasitic contamination on fresh vegetables sold in traditional markets in Hue City, Vietnam. Journal of Food and Nutrition Research. 2 (12): 959-964.

40. Dimitrios IT, Dimakopoulou DM, Atoniou PP, Tjamos EC. 2012 Biological control strategies of mycotoxigenic fungi and associated mycotoxins in Mediterranean basin crops. Phytopathologia Mediterranea 51 (1): $158-174$

41. Idu M, Omonigho SE, Erhabor JO, Efijuemue HM. 2010. Microbial load of some medicinal plants sold in some local markets in Abeokuta, Nigeria. Trop. J. Pharm. Res. 9 (3): 251.

42. Irshad S, Butt M, Younus H. 2011. In vitro antibacterial activity of Aloe Barbadensis Miller (Aloe Vera). Intl. R. J. Pharmaceuticals. 1 (4): 59-64 